\title{
RESISTANCE OF SOYBEAN GENOTYPES WITH LARGE SEED SIZE AND EARLY MATURITY AGAINST POD BORER, Etiella zinckenella TREITSCHKE
}

\author{
Marida Santi Yudha Ika Bayu \& Yusmani Prayogo \\ Indonesian Legumes and Tuber Crops Research Institute, Indonesia \\ J1. Raya Kendalpayak Km. 8 KP. 66, Malang 65101, East Java \\ E-mail: santi4.nov@gmail.com
}

\begin{abstract}
Resistance of soybean genotypes with large seed size and early maturity against pod borer, Etiella zinckenella treitschke. Pod borer is a major pest on soybean. The objective of this study was to determine the resistance of soybean genotypes against pod borer based on choice test. The experiment was conducted in green house and laboratory of Entomology, Indonesian Legumes and Tuber Crops Research Institute, using randomized block design with 16 soybean genotypes and three replicates. Planting dates was arranged such a way so as to sincronize the flowering time and pod formation of 16 soybean genotypes. A pairs of 4 days emerged adult pod borer were infested into each plant at R4 stage (21 days after flowering) for two days. The number of egg was observed at 2 days after infestation (DAI) and the number of larva and damaged intensity were observed at 14 DAI. The results showed that genotypes significantly affected egg and larval population, pod and seed damage intensity. The lowest egg and larval population found on Anjasmoro, 6.33 eggs and 10 individuals, respectively. The lowest intensity of pod damage found on Anjasmoro (27.74\%), and the lowest intensity of seed damage found on Malabar/Sinabung-68 (15.61\%). The resistance of soybean genotypes was non-preference as place to lay eggs and as feed. In conclusion, there were two genotypes showed consistently resistant (Anjasmoro and Malabar/Sinabung-68). These genotypes could be used as a source of genes for varietal improvement of soybean resistance against pod borer.
\end{abstract}

Key words: damaged intensity, Etiella zinckenella, resistance, soybean

\section{INTRODUCTION}

Soybean is the important food crop in tropical and sub tropical areas that contain high nutrition and suply a half of the global demand for protein and vegetable oil. In Indonesia, soybean production in 2014 was about 953 million tonnes (FAOSTAT, 2015). Since 1918, Indonesia through Indonesian Agency for Agricultural Reserach and Development have released several soybean varieties with large seed size $(>14 \mathrm{~g} / 100$ seeds) and have early maturity ( $<70$ days) (Adie \& Krisnawati, 2013). Large seeded and early matured soybean were more preferable by the farmer. Large seeded soybean are suitable as a raw material for tempeh. Soybean cultivation, however, has been under continuous threat due to the attack of pod borer, Etiella zinckenella Treitschke (Lepidoptera: Pyralidae) (Baliadi et al., 2011; Permana et al., 2012; Bayu \& Prayogo, 2014). Soybean yield losses caused by insect pests is one of the most important factors leading to the reduced production and productivity. Soybean yield losses caused by pod borer are difficult to be estimated because of the susceptibility of genotype, the control technology used, socioeconomic condition of farmers, and other environmental condition (Oliveira et al., 2014). Pod borer are considered as the most difficult soybean pests to be controlled due to larval feeding behavior. Larval spend most of the time during its stage inside the pod by consume the seed (Apriyanto et al., 2009).

Currently, most soybean growers used chemical insecticide to control pod borer without considering the recommended economic threshold. Effectiveness of chemical insecticide is very short even applied intensively during the growing season. It is because new emerged larva will go inside the pod directly. Hence, we have to consider the alternatives control method that more effective and environmentally friendly. Resistant varieties, cultural techniques, the use of natural enemies, the use of biopesticides, and chemical insecticides, are recommended for sustainable crop management (Chandler et al., 2011; Panizzi, 2013). The use of resistant variety offers stabilization the yield and has significant benefits rather than the use of chemical insecticides. It is also proved to be environmentally friendly, minimize the production costs, and often compatible with other pest control methods (Oki et al., 2012; Suharsono \& Sulistyowati, 2012). 
There are variability responses of soybean genotypes to pod borer (Amro et al., 2009; Taghizadeh et al., 2012). In general, soybean varieties that have been released in Indonesia are susceptible to insect pests, particularly against pod borer. According to Baliadi et al., 2011, Grobogan is less preferred by imago pod borer for oviposition, with eggs population about $0.6-2$ eggs per hill. Genotype IAC 100 and G100 H indicated resistant against pod borer based on choice test (Bayu et al., 2014; Bayu \& Prayogo, 2014; Kuswantoro et al., 2017). Soybean genetic variability has to be identified to provide gene sources in development of soybean that resistant to pod borer. The information of resistance of soybean genotypes against pod borer is required for considering the appropriate pest control technology. Moreover, nowadays, soybean with large seed size and have short duration is most preferable to be cultivated by the farmer. The objective of this study was to determine the resistance of soybean genotypes against pod borer, further could be released as a new variety resistance to pod borer with high yield potential.

\section{MATERIALS AND METHODS}

The experiment was conducted in Laboratory of Entomology and green house of Indonesian Legumes and Tuber Crops Research Institute, Malang, East Java. The experiment was arranged in randomized block design with three replicates. This experiment was designed to minimize the effect of environment variability on the distribution of E. zinckenella due to the wind direction and light. A total of 16 genotypes were evaluated for the resistance against pod borer. They were 12 large seed size and early maturity soybean genotypes (Sinabung/Argomulyo-8, Sinabung/Malabar16, Sinabung/Malabar-19, Argomulyo/Sinabung-34, Argomulyo/Sinabung-47, Argomulyo/Sinabung-52, Malabar/Sinabung-66, Malabar/Sinabung-68, L.Jateng/ Sinabung-85, Argomulyo/Sinabung-98, Anjasmoro, Grobogan), two resistant check genotypes (IAC 100 and $\mathrm{G} 100 \mathrm{H})$ (Baliadi et al., 2011; Bayu et al., 2014; Kuswantoro et al., 2017), and two susceptible check genotypes (Ichyou and Wilis) (Suharsono, 2006; Bayu et al., 2014).

Pod Borer Rearing. Population of pod borer (fifth instar larvae) originally collected from harvested soybean and dried on drying floor in Ngale Exprimental Station, Ngawi, East Java. Pod borer larvae were kept inside plastic box (h: $20 \mathrm{~cm}$ and $\Phi: 30 \mathrm{~cm}$ ), filled with sawdust, and reared in the laboratory until pupation. Pupae were collected and kept in plastic box covered with fresh soybean leaves to provide high humidity for about $80 \%$, an optimal condition required for the growth and development of pupae. Pupae were transferred into the cage made from iron frame (h: $50 \mathrm{~cm}$ and $\Phi 26 \mathrm{~cm}$ ), covered with a white tile fabric. Some cotton balls filled with $10 \%$ honey solution were hung on the top of the cage as feed for emerging adult. Feed was replaced everyday. Emerged adults were identified to distinguish their sex by using stereoscopic microscope (SZ40, Olympus Corporation, Tokyo, Japan). Only normal and healthy adults were used in the experiment. Adults were separated everyday to obtain individual with the same age. Four days old males and female were used as insect test.

Plant Culture. Each genotype was grown in pot $(\Phi=18 \mathrm{~cm}$ ) containing $10 \mathrm{~kg}$ of soil, mixed with manure in a ratio of $4: 1$, two plants/pot, two pots/genotype/ replicate. Planting dates were arranged in such a way that the flowering of 16 soybean genotypes occured at the same time in order to obtain pod with same condition. Each pot was fertilized with $0.4 \mathrm{~g}$ Urea and $1.2 \mathrm{~g}$ NPK at the sowing date. One pot was used as sample to observe egg population and the other one was used as sample to observe larvae number and pod and seed damaged. Watering was done as necessary. Sipermetrin was applied 8 day after sowing (DAS) to control bean fly. Sihalotrin was also applied at 14, 21 and 28 DAS to control foliage pests. In addition, the growth of soybean was improved by applying gandasil D and $\mathrm{B}$ at the same time of sihalotrin application.

Pod Borer Infestation. Evaluation of resistance to pod borer was performed in choice test. After 35 DAS, a total of 32 pot was enclosed in the screen cage $(6 \times 4 \times$ $1.8 \mathrm{~m}$ )/replicate. The screen cages were made of nylon fabric that is not translucent to adult pod borer. A pair of four days old pod borer adults were infested into each pot within screen cage at $\mathrm{R} 4$ stage of the soybean (56 $\mathrm{DAS}=21$ days after flowering) at $\quad 14.00 \mathrm{am}$ for two days. All variables such as number of pods, seeds, eggs and larvae, and the intensity of pod and seed damaged were measured per pot based ( 2 plants).

Egg number was observed 2 days after infestation (DAI). Samples were taken by cutting the stem, putting them inside plastic bag, giving a label, and then bring them to the laboratory. In the laboratory, we separated pod from the stem carefully, then counted the number of egg laid by female on stem and pod under stereoscopic microscope. The number of larval and the number of pod and seed damaged by larva were counted at day 14 
DAI using the same method with egg number observation.

One pod of each genotype was taken for measurements of pod and characteristic of trichome. Pod was measured by using millimeter block. Trichome characteristic was observed under binocular microscope. Trichome density measurement was carried out on the area of $2 \mathrm{~mm}^{2}$. The observations of trichome length were performed by cuting one trichome and placing it above glass preparation. Data were subjected to analysis of variance (ANOVA) and mean values were compared using Tukey's test when significant $\mathrm{F}$ values were obtained ( $\alpha=0.05$; SPSS ver. 22 ).

The damage intensity was calculated as follows:

$$
\mathrm{I}=\frac{\mathrm{n}}{\mathrm{N}} \times 100 \%
$$

$\mathrm{I}=$ Percentage of pod or seed damaged

$\mathrm{n}=$ Number of pod or seed damaged

$\mathrm{N}=$ Total number of pod or seed

The criteria of resistance follow the method developed by (Baliadi et al., 2011; Bayu et al., 2014) as follows: $0-\mathrm{x}=\mathrm{HR}$ (Highly Resistant), $(\mathrm{x}-(\mathrm{x}+\mathrm{a})=$ $\mathrm{R}($ Resistant $),(x+a)-(x+2 a)=$ MR (Moderately
Resistant $),(x+2 a)-(x+3 a)=S$ (Susceptible $)$, and $(x+3 a)-(x+x n)=$ HS (Highly Susceptible), in which a $=(x n-x) / 4$. $x n$ is the highest value and $x$ is the lowest value in each variable (the number of eggs, the number of larvae, and the intensity of pod and damaged seeds).

\section{RESULTS AND DISCUSSION}

Egg Number. Analysis of variance showed that means of egg numbers laid by females on pods were significantly different between genotypes (Table 1). The average number of eggs was 23.8 (range 6.3-44.3 eggs/ pot. Based on the oviposition preference, there was one genotype indicated highly resistant $($ Anjasmoro $=6.3$ eggs/pot) and one genotype as resistant (Grobogan $=$ 11.7 eggs/pot). Both genotypes were less preffered for oviposition. Moreover, there were four genotypes indicated as moderately resistant, namely Sinabung/ Malabar-16, Malabar/Sinabung-66, Malabar/Sinabung68, and Argomulyo/Sinabung-98. These genotypes showed different numbers of egg; 18.3, 17.3, 16.7, and 21.3 eggs/pot, respectively.

Anjasmoro was totally avoided in previous oviposition choice test containing 30 genotypes (Baliadi et al., 2011). There was no egg found on the pod of

Table 1. Number of egg and number of larva E. zinckenella on 16 soybean genotypes (Malang, East Java, Indonesia)

\begin{tabular}{cllccc}
\hline No & \multicolumn{1}{c}{ Genotype } & $\begin{array}{l}\text { Number of egg } \\
\text { (eggs/2 plants) }\end{array}$ & Category & $\begin{array}{c}\text { Number of larvae } \\
\text { (individuals/2 plants) }\end{array}$ & Category \\
\hline 1 & Sinabung/Argomulyo-8 & $40.3 \mathrm{ab}$ & $\mathrm{HS}$ & $44.0 \mathrm{abc}$ & $\mathrm{HS}$ \\
2 & Sinabung/Malabar-16 & $18.3 \mathrm{cde}$ & $\mathrm{MR}$ & $55.0 \mathrm{a}$ & $\mathrm{HS}$ \\
3 & Sinabung/Malabar-19 & $28.0 \mathrm{abcd}$ & $\mathrm{S}$ & $47.3 \mathrm{ab}$ & $\mathrm{HS}$ \\
4 & Argomulyo/Sinabung-34 & $28.0 \mathrm{abcd}$ & $\mathrm{S}$ & $53.3 \mathrm{a}$ & $\mathrm{HS}$ \\
5 & Argomulyo/Sinabung-47 & $41.7 \mathrm{ab}$ & $\mathrm{HS}$ & $29.0 \mathrm{abc}$ & $\mathrm{MR}$ \\
6 & Argomulyo/Sinabung-52 & $31.3 \mathrm{abc}$ & $\mathrm{S}$ & $30.3 \mathrm{abc}$ & $\mathrm{MR}$ \\
7 & Malabar/Sinabung-66 & $17.3 \mathrm{cde}$ & $\mathrm{MR}$ & $38.7 \mathrm{abc}$ & $\mathrm{S}$ \\
8 & Malabar/Sinabung-68 & $16.7 \mathrm{cde}$ & $\mathrm{MR}$ & $20.3 \mathrm{abc}$ & $\mathrm{R}$ \\
9 & L.Jateng/Sinabung-85 & $31.3 \mathrm{abc}$ & $\mathrm{S}$ & $38.3 \mathrm{abc}$ & $\mathrm{S}$ \\
10 & Argomulyo/Sinabung-98 & $21.3 \mathrm{bcde}$ & $\mathrm{MR}$ & $43.0 \mathrm{abc}$ & $\mathrm{S}$ \\
11 & Anjasmoro & $6.3 \mathrm{e}$ & $\mathrm{HR}$ & $10.0 \mathrm{c}$ & $\mathrm{HR}$ \\
12 & Grobogan & $11.7 \mathrm{cde}$ & $\mathrm{R}$ & $35.3 \mathrm{abc}$ & $\mathrm{S}$ \\
13 & IAC 100 & $10.3 \mathrm{de}$ & $\mathrm{R}$ & $12.7 \mathrm{bc}$ & $\mathrm{R}$ \\
14 & G 100 H & $23.7 \mathrm{abcde}$ & $\mathrm{MR}$ & $26.3 \mathrm{abc}$ & $\mathrm{MR}$ \\
15 & Ichyou & $10.0 \mathrm{de}$ & $\mathrm{R}$ & $25.0 \mathrm{abc}$ & $\mathrm{MR}$ \\
16 & Wilis & $44.3 \mathrm{a}$ & $\mathrm{HS}$ & $45.7 \mathrm{ab}$ & $\mathrm{HS}$ \\
\hline
\end{tabular}

Value within the same column followed by the same letter are not significantly different at the 0.05 level according to Tukey's test. $\mathrm{HR}=$ highly resistant; $\mathrm{R}=$ resistant; $\mathrm{MR}=$ moderately resistant; $\mathrm{S}=$ susceptible; $\mathrm{HS}=$ highly susceptible. 
Anjasmoro two days after infestation by adult pod borer. Our results are slightly different with previous study, 6 eggs/pot were found on Anjasmoro and we put it in the category of highly resistant. The possible explanation for this observed difference was the difference of numbers of genotype used in this and previous tests. In this study we used 16 genotypes, less than that of Baliadi et al. (2011), leading to higher chance that Anjasmoro was also chosen by pod borer for oviposition. In this study, Grobogan also showed resistance against pod borer based on egg number. This result is consistent with previous study that only 1 egg found per plant (Figure 1). Anjasmoro and Grobogan are most preferable by the farmer because both of them showed high yield, larger seed size, and early maturity for Grobogan.

Our finding suggests that each genotype has different morphological characters that may affect preferences of the adult to come or interact with the plant. Oviposition choice test provides opportunity for pod borer to select the most preferred host. The differences in the number of eggs found on each genotype may be related to physical factor such as the trichome densities, trichome position, and trichome length, which makes pod borers get difficulty to oviposit. Genotype with less or no trichome usually not preferred by the insect for oviposition because it facillitates the predators such as Paederus sp. to find and prey the egg. However, based on the observations on Ichyou (genotype with no trichome) in laboratory, adult pod borer laid egg under the petals at the base of the pod. We cannot ignore indirect effects of the secondary metabolite or protein contained in each genotype on the resistance level. For example, flavonoid offers protection against insect pest and the high isoflavon content will increace the resictance of soyben to stink bug pest (Vogt, 2010; Zavala et al., 2015). It is possible that the levels of plant resistance are also affected by such chemical compound or secondary metabolite on each plant, which subsequently influences herbivore performance.

Larval Number. The differences of soybean genotypes also significantly affected pod borer larval number (Table
1). The average larval number on the genotypes tested was 34.6 (range 10-55 individuals/pot). The highest larval number was found on the Sinabung/Malabar-16, followed by Argomulyo/Sinabung-34, an indication that all were highly susceptible to larval feeding of pod borer. Anjasmoro showed highly resistant with lower larva density (10 larvae/pot), whereas Malabar/Sinabung 68 genotype indicated as resistant with 12 larvae/pot). The type of resistance of these two genotypes was antixenosis or not selected by the larva. The possible explanation for this patern is the high density of trichome difficulty causes for larva to reach pod wall and find the food source. Consequently, larvae migrate and seek appropriate pods from other genotypes. In addition, lesspreferred genotypes by the larva may be have certain chemical compound that influences larval performance which can be detected early before drill the pod. Further research is needed to prove that those genotypes contain chemical compounds which deterred pod borer and causing larval mortality.

Genotype IAC 100 also known to have antibiosis resistance mechanism, causing growth retardation, lengthening larval development, and decreasing larval weight. Presumably, other resistant genotype has similar mechanism against pod borer. According to Mudjiono (1998), insect will act scatter in area without any cue, colonize near a food source to ensure their survival, close to the presence of chemical compound or stay away from the plant that contain dangerous chemical compound as a respon to the plant performance. This act may effect on insect eating, mating, and oviposition behaviors.

Pod Size and Trichome Characteristic. Pod size and trichome length was significantly different in all of genotypes (Table 2). Trichome density was categorized as high and low. IAC 100 has high trichome density but less preferred by adult of pod borer for oviposition. Argomulyo/Sinabung-98 also showed similar characteristic and response of adult pod borer as IAC 100. Presumably, high density and straight position of trichome deterred pod borer to lay egg because the

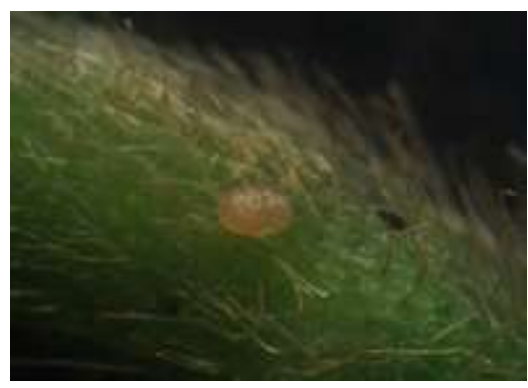

Figure 1. Egg laid by female on soybean pod 
ovipositor have difficulty to reach pod wall. Moreover, stright position of trichome affected egg position in which egg will fall down easily. According to Suharsono (2006), oviposition preference of soybean pod borer was affected by the trichome. He also stated that egg population was low on the genotypes with high trichome density (IAC 100) than on the genotype with low trichome density (Wilis).

Trichome length also influenced adult pod borer oviposition. Sinabung/Malabar-16, Argomulyo/Sinabung98, Anjasmoro, IAC 100, and G $100 \mathrm{H}$ have longer trichome than other genotypes and indicated less preferred for oviposition because of difficulty of ovipositor reaching pod wall. Trichome density and structure, trichome position, and trichome length have significant role in plant protection against insect pests as the first line of defense (War et al., 2012). Malabar/ Sinabung-66 showed the longest and widest pod, while Anjasmoro showed the shortest and narrowed pod (Table 2). However, both genotypes categorized resistant based on egg number. It seems that pod size did not affect oviposition preference of pod borer adult.

Pod and Seed Damaged Intensity. Pod and seed damaged intensity was significantly influenced by genotypes (Table 3 ). The highest percentage of pod damage by E. zinckenella larvae was observed on Sinabung/Argomulyo-8 (62.4\%), while the lowest percentage was on IAC $100(14.0 \%)$. Based on the pod damaged intensity within genotypes tested compared with resistant check, there were no genotype that can be categorized as resistant, but they are moderately resistant, namely Anjasmoro (27.7\%), Sinabung/ Malabar-19 (34.77\%), Argomulyo/Sinabung-52 (36.03\%), and Malabar/Sinabung-68 (31.48\%) (Table $3)$.

Seed damaged intensity on 16 genotypes ranged from $6.63-34.09 \%$ (Table 3). Based on the seed damaged intensity, there is no genotype indicated as resistant agains pod borer. However, there were five genotypes indicated as moderately resistant against pod borer, namely Sinabung/Malabar-19 (19.85\%), Argomulyo/Sinabung-52 (16.15\%), Malabar/Sinabung66 (20.39\%), Malabar/Sinabung-68 (15.61\%), and Anjasmoro (17.81\%).

Resistance to pod borer was reported to be associated with pod morphological factors (antixenosis or non-preference) as well as antibiosis factors (Permana et al., 2012; War et al., 2012). Our study revealed that Anjasmoro and Malabar/Sinabung-68 showed consistently resistant to moderate-resistant based on egg and larval number, and pod/seed damaged intensity. Antixenosis is the mechanism of resistance exhibited by the host plants, in which deters the insects from oviposition, feeding, seeking shelter, and colonization (Afzal et al., 2009; Morando et al., 2015). This mechanism occurred maybe due to certain plant structural traits or allelochemicals, or various interactions

Table 2. Pod size, trichome density, trichome position, and trichome length on 16 soybean genotypes (Malang, East Java, Indonesia)

\begin{tabular}{clccccl}
\hline No & \multicolumn{1}{c}{ Genotype } & $\begin{array}{c}\text { Trichome } \\
\text { density }\end{array}$ & Trichome position & $\begin{array}{c}\text { Trichome } \\
\text { length }(\mu \mathrm{m})\end{array}$ & $\begin{array}{c}\text { Pod length } \\
(\mathrm{cm})\end{array}$ & $\begin{array}{c}\text { Pod width } \\
(\mathrm{cm})\end{array}$ \\
\hline 1 & Sinabung/Argomulyo-8 & High & Straight skewed & $418.33 \mathrm{bcd}$ & $4.1 \mathrm{def}$ & $0.9 \mathrm{abc}$ \\
2 & Sinabung/Malabar-16 & Low & Straight skewed & $522.89 \mathrm{a}$ & $4.1 \mathrm{def}$ & $0.86 \mathrm{bcd}$ \\
3 & Sinabung/Malabar-19 & Low & Straight skewed & $367.33 \mathrm{def}$ & $3.4 \mathrm{i}$ & $0.74 \mathrm{e}$ \\
4 & Argomulyo/Sinabung-34 & High & Straight skewed & $439.44 \mathrm{bc}$ & $4.2 \mathrm{de}$ & $0.81 \mathrm{de}$ \\
5 & Argomulyo/Sinabung-47 & High & Straight skewed & $348.00 \mathrm{ef}$ & $4.6 \mathrm{bc}$ & $0.90 \mathrm{abc}$ \\
6 & Argomulyo/Sinabung-52 & High & Straight skewed & $221.56 \mathrm{~h}$ & $4.1 \mathrm{def}$ & $0.80 \mathrm{de}$ \\
7 & Malabar/Sinabung-66 & Low & Straight skewed & $321.78 \mathrm{fg}$ & $5.2 \mathrm{a}$ & $0.96 \mathrm{a}$ \\
8 & Malabar/Sinabung-68 & Low & Straight skewed & $277.89 \mathrm{~g}$ & $4.1 \mathrm{def}$ & $0.89 \mathrm{abc}$ \\
9 & L.Jateng/Sinabung-85 & Low & Straight skewed & $357.11 \mathrm{def}$ & $4.7 \mathrm{~b}$ & $0.83 \mathrm{~cd}$ \\
10 & Argomulyo/Sinabung-98 & High & Straight skewed & $452.67 \mathrm{ab}$ & $4.3 \mathrm{~cd}$ & $0.87 \mathrm{bcd}$ \\
11 & Anjasmoro & Low & Straight & $472.56 \mathrm{ab}$ & $2.7 \mathrm{k}$ & $0.59 \mathrm{f}$ \\
12 & Grobogan & Low & Straight & $372.33 \mathrm{def}$ & $3.8 \mathrm{fgh}$ & $0.91 \mathrm{ab}$ \\
13 & IAC 100 & High & Straight & $406.11 \mathrm{bcde}$ & $3.8 \mathrm{gh}$ & $0.84 \mathrm{bcd}$ \\
14 & G 100 H & High & Straight skewed & $408.11 \mathrm{bcde}$ & $4.0 \mathrm{efg}$ & $0.87 \mathrm{bcd}$ \\
15 & Ichyou & No & No Trichome & $0.00 \mathrm{i}$ & $3.1 \mathrm{j}$ & $0.84 \mathrm{bcd}$ \\
16 & Wilis & Low & Straight & $455.11 \mathrm{ab}$ & $3.6 \mathrm{hi}$ & $0.76 \mathrm{e}$ \\
\hline
\end{tabular}

Value within the same column followed by the same letter are not significantly different at the 0.05 level according to Tukey's test. 
Table 3. Pod and seed damage intensity (\%/genotipe) on 16 soybean genotypes (Malang, East Java, Indonesia)

\begin{tabular}{|c|c|c|c|c|c|}
\hline No & Genotype & $\begin{array}{l}\text { Pod damaged } \\
\text { (\%/pot) }\end{array}$ & Category & $\begin{array}{l}\text { Seed damaged } \\
\quad(\% / \text { pot })\end{array}$ & Category \\
\hline 1 & Sinabung/Argomulyo-8 & $62.4 \mathrm{a}$ & HS & $32.7 \mathrm{a}$ & HS \\
\hline 2 & Sinabung/Malabar-16 & $47.9 \mathrm{ab}$ & $\mathrm{S}$ & $34.0 \mathrm{a}$ & HS \\
\hline 3 & Sinabung/Malabar-19 & $34.8 \mathrm{abc}$ & MR & $19.8 \mathrm{ab}$ & MR \\
\hline 4 & Argomulyo/Sinabung-34 & $43.0 \mathrm{ab}$ & $\mathrm{S}$ & $22.5 \mathrm{ab}$ & $\mathrm{S}$ \\
\hline 5 & Argomulyo/Sinabung-47 & $50.0 \mathrm{ab}$ & $\mathrm{S}$ & $25.5 \mathrm{ab}$ & $\mathrm{S}$ \\
\hline 6 & Argomulyo/Sinabung-52 & $36.0 \mathrm{abc}$ & MR & $16.1 \mathrm{ab}$ & MR \\
\hline 7 & Malabar/Sinabung-66 & $39.7 \mathrm{abc}$ & S & $20.4 \mathrm{ab}$ & MR \\
\hline 8 & Malabar/Sinabung-68 & $31.5 \mathrm{bc}$ & MR & $15.6 \mathrm{ab}$ & MR \\
\hline 9 & L.Jateng/Sinabung-85 & $40.0 \mathrm{abc}$ & S & $23.3 \mathrm{ab}$ & S \\
\hline 10 & Argomulyo/Sinabung-98 & $45.2 \mathrm{ab}$ & S & $24.0 \mathrm{ab}$ & S \\
\hline 11 & Anjasmoro & $27.7 \mathrm{bc}$ & MR & $17.8 \mathrm{ab}$ & MR \\
\hline 12 & Grobogan & $48.3 \mathrm{ab}$ & S & $30.3 \mathrm{a}$ & HS \\
\hline 13 & IAC 100 & $14.0 \mathrm{c}$ & $\mathrm{R}$ & $6.6 \mathrm{~b}$ & $\mathrm{R}$ \\
\hline 14 & $\mathrm{G} 100 \mathrm{H}$ & $29.7 \mathrm{bc}$ & MR & $14.7 \mathrm{ab}$ & MR \\
\hline 15 & Ichyou & $33.0 \mathrm{bc}$ & MR & $19.4 \mathrm{ab}$ & MR \\
\hline 16 & Wilis & $38.6 \mathrm{abc}$ & $\mathrm{S}$ & $23.4 \mathrm{ab}$ & S \\
\hline
\end{tabular}

Value within the same column followed by the same letter are not significantly different at the 0.05 level according to Tukey's test.

among those factors (Gogi et al., 2010). According to Souza et al. (2014), IAC 100 exhibited antibiosis against Spodoptera eridania in which delayed larval and total cycle development and also reduced survival rates. Moreover, Eduardo et al. (2016) also reported that some common bean caused longer pest life cycles, and low consumption and percentage of emerging adults of Bruchidae, indicates that the genotypes exhibites antibiosis resistance. Presumably, Anjasmoro and Malabar/Sinabung-68 also exhibited antibiosis resistance against $E$. zinckenella because there was rejection of larva to feed. Further studies must be carried out in both genotypes to discriminate the main mechanisms responsible for the expression of resistance against the pod borer.

\section{CONCLUSION}

Based on the research, we conclude that Anjasmoro and Malabar/Sinabung-68 indicated as resistant genotypes against pod borer based on the population of egg and larvae, and on the intensity of damaged pod and seed. These two genotypes could be used as as a source of genes for varietal improvement of soybean resistance to pod borer. Understanding the mechanism of resistance will undoubtedly help in the development of soybean variety with improved pest resistance in order to reduce the intensive use of chemical insecticide.

\section{ACKNOWLEDGEMENT}

The author acknowledge our funding source for this research, the Ministry of Agriculture, Republic of Indonesia, Indonesian Agency for Agriculture Research and Development (IAARD) through the DIPA.

\section{REFERENCES}

Adie MM \& Krinawati A. 2013. Biology of soybean. In: Sumarno, Suyamto, Widjono A, Hermanto, \& Kasim H (Eds.). Soybean, Production and Development Techniques. pp. 45-73. Indonesian Center for Food Crops Research and Development. Indonesian Agency for Agricultural Research and Development.

Afzal M, Nazir Z, Bashir MH, \& Khan BS. 2009. Analysis of host plant resistance in some genotypes of maize against Chilo partellus (Swinhoe) (Pyralidae: Lepidoptera). Pak. J. Bot. 4(1): 421-428.

Amro MA, Abdel-Moniem ASH, \& Omar MS. 2009. Determination of the resistance status of experimental soybeans to the lima bean pod borer, Etiella zinckenella Treitschke and the Whitefly, Bemisia tabaci Gennadius at El-Dakhla Oases, New Valley, Egypt. Arch. Phytopathol. and Plant Protection. 42(6): 552-558. 
Apriyanto D, Gunawan E, \& Sunardi T. 2009. Resistance of some groundnut cultivars to soybean pod borer Etiella zinckenella Treit (Lepidoptera: Pyralidae). J. HPT Tropika. 9(1): 1-7.

Baliadi Y, Purwantoro, \& Tengkano W. 2011. Identification of early maturing soybean genotypes that resistant to pod borer pest Etiella Zinckenella Tr. (Lepiodoptera: Pyralidae). In: Adie MM, Solihin, Rahmianna AA, Tastra IK, Rozi F, Hermanto, Sulistyo A, \& Sumartini (Eds.). Proceeding of National Seminar of Legume and Tuber Crops Research Results 2010. pp. 217-232. Indonesian Center for Food Crops Research and Development, Bogor.

Bayu MSYI \& Prayogo Y. 2014. Evaluation of resistance of soybean genotypes against pod borer, Etiella Zinckenella Tr. to support environmentally friendly pest control. In: Jamhuri M, Rozi F, \& Ismail (Eds.). Proceeding of The $5^{\text {th }}$ International Conference on Green Technology.pp. 285-291. Faculty of Science and Technology Maulana Malik Ibrahim State Islamic University of Malang, Malang.

Bayu MSYI, Baliadi Y, Suhartina, \& Tengkano W. 2014. Response of soybean promising lines for acid soil and drought tolerances to pod borer. In: Saleh N, Harsono A, Nugrahaeni N, Rahmianna AA, Solihin, Yusuf M, Heriyanto, Tastra IK, Adie MM, Hermanto, \& Harnowo D (Eds.). Proceeding of National Seminar of Legume and Tuber Crops Research Results 2013. pp. 245-255. Indonesian Center for Food Crops Research and Development, Bogor.

Chandler D, Bailey AS, Tatchell GM, Davidson G, Greaves J, \& Grant WP. 2011. The development, regulation and use of biopesticides for integrated pest management. Philos. Trans. R. Soc. Lond. B. Biol. Sci. 366(1573): 1987-1998.

Eduardo WI, Boica-Jinior AL, Oliveira de Moraes RF, Chiorato AF, Perlatti B, \& Forim MR. 2016. Antibiosis levels of common bean genotypes toward Zabrotes subfasciatus (Boheman) (Coleoptera: Bruchidae) and its correlation with flavonoids. Journal of Stored Products Research. 67: 63-70.

FAO. 2015. Agriculture Organization of the United Nations (Statistical database). FAOSTAT, Roma.
Gogi MD, Asfaq M, Arif MJ, \& Khan MA. 2010. Biophysical bases of antixenotic mechanism of resistance in bitter-gourd (Momordica Charantia L., Cucurbitacae) against melon fruit fly, Bactrocera cucurbitae (Coquillett) (Diptera: Tephritidae). Pak. J. Bot. 42(2): 1251-1266.

Kuswantoro H, Bayu MSYI, Baliadi Y, \& Tengkano W. 2017. Resistance of advanced soybean lines to pod borrer (Etiella zinckenella). Biosaintifika. 9(2): 317-324.

Morando R, Baldin ELL, Cruz PL, Lourencao AL, \& Chiorato AF. 2015. Antixenosis of bean genotypes to Chrysodeixis includens (Lepidoptera: Noctuidae). Pesq. Agropec. Bras. 50(6): 450458.

Mudjiono G. 1998. Reciprocal relationship Insect-Plant. Malang, Faculty of Agriculture, Brawijaya.

Oki N, Komatsu K, Sayama T, Ishimoto M, Takahashi M, \& Takahashi M. 2012. Genetic analysis of antixenosis resistance to the common cutworm (Spodoptera litura Fabricius) and its relationship with pubescence characteristics in soybean (Glycine max (L.) Merr.). Breed. Sci. 61(5): 608-617.

Oliveira CM, Auad AM, Mendes SM, \& Frizzas MR. 2014. Crop losses and the economic impact of insect pests on Brazilian Agriculture. Crop Protection. 56: 50-54.

Panizzi AR. 2013. History and contemporary perspectives of the integrated pest management of soybean in Brazil. Neotrop. Entomol. 42(2): 119-127.

Permana AD, Johari A, Putra RE, Sastrodiharjo S, \& Ahmad I. 2012. The influence of trichome characters of soybean (Glycine max Merrill) on oviposition preference of soybean pod borer Etiella zinckenella Treitschke (Lepidoptera: Pyralidae) in Indonesia. J. Entomol. Nematol. 4(3): 15-21.

Souza BHS, Silva AG, Janini JC, \& Boica-Junior AL. 2014. Antibiosis in soybean genotypes and the resistance levels to Spodoptera eridania (Cramer) (Lepidoptera: Noctuidae). Neotrop. Entomol. 43(6): 582-587.

Suharsono. 2006. Antixenosis morfologis salah satu faktor ketahanan kedelai terhadap hama pemakan polong. Bul. Palawija. 12: 29-34. 
Suharsono \& Sulistyowati L. 2012. Expression of resistance of soybean to the pod sucking bug Riptortus linearis F. (Hemiptera: Coreidae). Agrivita 34(1): 55-59.

Taghizadeh R, Talebi AA, Fathipour Y, \& Khalghani J. 2012. Effect of ten soybean cultivars on development and reproduction of lima bean pod borer, Etiella zinckenella (Lepidoptera: Pyralidae) under laboratory conditions. Appl. Ent. Phytopath. 79(2): 15-28.

Vogt T. 2010. Phenylpropanoid biosynthesis. Mol. Plant. 3(1): 2-20.
War AR, Paulraj MG, Ahmad T, Buhroo A, Hussain B, Ignacimuthu S, \& Sharma HC. 2012. Mechanisms of plant defense against insect herbivores. Plant Signal Behav. 7(10): 1306-1320.

Zavala JA, Mazza CA, Dillon FM, Chludil HD, \& Ballare CL. 2015. Soybean resistance to stink bugs (Nezara viridula and Piezodorus guildinii) increases with exposure to solar UV-B radiation and correlates with isoflavonoid content in pods under field conditions. Plant Cell Environ. 38(5): 920-928. 